NBER WORKING PAPER SERIES

\title{
NATURE AND NURTURE IN THE INTERGENERATIONAL TRANSMISSION OF SOCIOECONOMIC STATUS: EVIDENCE FROM SWEDISH CHILDREN AND THEIR BIOLOGICAL AND REARING PARENTS
}

\author{
Anders Björklund \\ Markus Jäntti \\ Gary Solon \\ Working Paper 12985 \\ http://www.nber.org/papers/w12985
}

\author{
NATIONAL BUREAU OF ECONOMIC RESEARCH \\ 1050 Massachusetts Avenue \\ Cambridge, MA 02138 \\ March 2007
}

A research grant from the Swedish Council for Working Life and Social Research is gratefully acknowledged by Anders Björklund. The authors also are grateful for comments from Kerwin Charles, Lucas Davis, and seminar participants at Harvard's Kennedy School, the National Bureau of Economic Research, Stockholm University, the University of Amsterdam, the University of California at Davis, and the 2006 ESPE meetings in Verona. The views expressed herein are those of the author(s) and do not necessarily reflect the views of the National Bureau of Economic Research.

(C) 2007 by Anders Björklund, Markus Jäntti, and Gary Solon. All rights reserved. Short sections of text, not to exceed two paragraphs, may be quoted without explicit permission provided that full credit, including (๑) notice, is given to the source. 
Nature and Nurture in the Intergenerational Transmission of Socioeconomic Status: Evidence from Swedish Children and Their Biological and Rearing Parents

Anders Björklund, Markus Jäntti, and Gary Solon

NBER Working Paper No. 12985

March 2007

JEL No. J1,J24,J62

\begin{abstract} association between sons' and daughters' socioeconomic outcomes and those of their biological and mother with a stepfather, raised by the biological father without a stepmother, raised by the biological most remarkable feature of our data set is that it contains information on the biological parents even intergenerational associations in all six family types. Our results suggest substantial roles for both pre-birth and post-birth factors.

Anders Björklund

Swedish Institute for Social Research

Stockholm University

SE-10691 Stockholm

Sweden

anders@ sofi.su.se

Markus Jäntti

Department of Economics and Statistics

Abo Akademi University

FIN-20500, Abo

Finland

markus.jantti@abo.fi

Gary Solon

Department of Economics

Lorch Hall

University of Michigan

611 Tappan Street

Ann Arbor, MI 48109-1220

and NBER

gsolon@umich.edu
\end{abstract}

This study uses an extraordinary Swedish data set to explore the sources of the intergenerational transmission of socioeconomic status. Merging data from administrative sources and censuses, we investigate the rearing parents. Our analysis focuses on children raised in six different family circumstances: raised by both biological parents, raised by the biological mother without a stepfather, raised by the biological father with a stepmother, and raised by two adoptive parents. Relative to the existing literature, the when they are not the rearing parents. We specify a simple additive model of pre-birth (including genetic) and post-birth influences and examine the model's ability to provide a unified account of the 


\title{
Nature and Nurture in the Intergenerational Transmission of Socioeconomic Status: Evidence from Swedish Children and Their Biological and Rearing Parents
}

\begin{abstract}
1. Introduction
Over the last two decades, a growing empirical literature has demonstrated that the intergenerational transmission of economic status is stronger than we used to believe (Solon, 1999 and forthcoming). Now we need to learn more about why intergenerational transmission is as strong (and as weak) as it is - that is, we need to find out more about the causal processes underlying the observed statistical associations between parents' and children’s socioeconomic outcomes.
\end{abstract}

The theoretical literature (for example, Becker and Tomes, 1979 and 1986; Solon, 2004) recognizes that many causal processes are at work. Higher-income parents have greater wherewithal to invest in their children’s education, health, and so forth. Beyond conscious decisions to invest in their children's human capital, parents (as well as other relatives and neighbors) also may influence children’s economic outcomes through “cultural inheritance,” for instance, through the examples they set for work effort, learning, interpersonal interactions, etc. And, in addition to these environmental influences, parents transmit to their children genetic traits that may foster or impede economic success.

Even at the very broad-brush level of nature vs. nurture, it is notoriously difficult to sort out these causal processes with the "observational” data available to us. One promising, though problematic, approach is to contrast the parent-child associations in socioeconomic outcomes across family types with different degrees of environmental and genetic connectedness. For example, if adopted children were assigned to biologically unrelated adoptive parents in a purely random fashion, then any statistical association of outcomes between the adoptive children and parents would have to stem solely from environmental causes. 
Indeed, several researchers already have studied adoptive families’ intergenerational associations in education or income. Taken together, the results in Scarr and Weinberg (1994), Sacerdote (2000), Das and Sjogren (2002), Plug (2004), and Plug and Vijverberg (2005) do suggest a positive association between children's and parents' education and income in adoptive families, and the association is statistically significant when the sample sizes are large enough. On the other hand, the intergenerational associations observed in samples of adoptive families often are distinctly smaller than those typically observed in general samples, in which most of the rearing parents are also biological parents. ${ }^{1}$

As the authors of some of these studies have emphasized, intergenerational associations in adoptive families do not identify just environmental effects if adoptions are subject to “selective placement.” Scarr and Weinberg (1994, p. 321), for example, note that “adoption agencies often place infants selectively by matching natural and adoptive parent characteristics, such as education, occupation, and impressions about intelligence.” In that case, if the genetic influence of the biological parents is not accounted for, statistical associations between the outcomes of adopted children and their adoptive parents could reflect a combination of the adoptive parents’ environmental influences and the correlated genetic inheritance.

Two recent studies have dealt with this issue in different ways. Sacerdote (2007) studies a particular adoptees subpopulation (Korean-born children adopted into U.S. families through Holt International Children’s Services) within which the placements were approximately random. He still finds a significantly positive (but small) association in the education of the adoptees and their adoptive mothers. He also finds a considerably larger association for some of

\footnotetext{
${ }^{1}$ Björklund and Chadwick (2003) report a similar result for Swedish “non-biological fathers,” who include stepfathers as well as adoptive fathers. A large literature has studied adoptive families' intergenerational associations in other outcomes, such as IQ and personality traits. Another relevant literature has studied correlations among siblings with varying degrees of genetic and environmental connectedness (see Björklund, Jäntti, and Solon, 2005, and the references therein). Also, Biblarz, Raftery, and Bucur (1997) and Biblarz and Raftery (1999) have examined differences across family types in the intergenerational transmission of occupational status.
} 
the same mothers and their biological children, but it is hard to tell what to make of the latter result given the endogeneity of these mothers' decisions to adopt. ${ }^{2}$

Using a large Swedish data base, Björklund, Lindahl, and Plug (2006) take an alternative approach. Exploiting their unusual access to information on the biological as well as the adoptive parents, they directly account for characteristics of the biological parents. For example, they estimate a regression equation for adopted children's years of education in which the explanatory variables include the years of education of all four parents - the biological mother and father and the adoptive mother and father. In this "horse race" among parental variables, all the horses place, in the sense that all the coefficient estimates are positive (usually significantly so). The coefficient estimates for the biological mother and father are respectively 0.101 and 0.094, and those for the adoptive mother and father are 0.021 and 0.094 . These results and others in the paper are suggestive of roles for both nature and nurture in the determination of education and income.

When Björklund, Lindahl, and Plug estimate the intergenerational education regression for children raised by their biological parents, the coefficient estimates are 0.158 for the mother and 0.170 for the father. These estimates might be construed as combining the effects of nature and nurture. An intriguing pattern is that the 0.158 estimate for the mother who rears her biological child is fairly close to the $0.122(0.101+0.021)$ sum of the estimates for the biological and adoptive mothers of an adopted child. Similarly, the 0.170 estimate for the father who rears his biological child is close to the $0.188(0.094+0.094)$ sum of the estimates for the two fathers of an adopted child.

Reacting to this pattern, the present paper explores the possibility that an almost absurdly simple model of additive pre-birth and post-birth parental effects can account for

\footnotetext{
${ }^{2}$ For example, if disabilities or other problems with a biological child induce parents to adopt their next child, the biological child of the adoptive parents will be systematically unrepresentative of the broader population of biological children.
} 
intergenerational associations in socioeconomic status across a variety of family types. Using the same extraordinary Swedish data set used by Björklund, Lindahl, and Plug, we analyze intergenerational associations not only for adoptive children and children raised by their biological mother and father, but also for four other samples in which the children were raised by one biological parent with the other absent at least some of the time, with or without a stepparent in the household.

Section 2 of the paper describes the data set. Section 3 overviews our model and estimation methods. Section 4 presents estimates of intergenerational regression equations for all six family types and then fits a unified model to the constellation of regression results. Section 5 summarizes our findings.

\section{Data}

Our data set merges information from several registers held by Statistics Sweden. We start with two basic samples from Statistics Sweden’s population register. The first is a 20 percent random sample of all non-adopted persons born in Sweden between January 1962 and September 1965. The second consists of all adopted persons born in Sweden during that time period. We draw only those adopted by both a mother and father, so stepchild adoptions are not included in our adoptees sample. ${ }^{3}$ In both samples, we use only individuals alive and living in Sweden as of 1999.

The adoption information in the population register comes from Sweden’s judicial adoption process. Björklund, Lindahl, and Plug (2006) provide a detailed discussion of that process, the essentials of which we summarize here. Each adoption decision was made by a Swedish court after a formal application by the adoptive parents. In each case, the court was

\footnotetext{
${ }^{3}$ In the cohorts born in Sweden during 1962-1965, around 1,000 children a year were adopted by both a mother and father. In subsequent years, this number fell rapidly, and international adoptions began to replace adoptions of native-born children.
} 
advised by a local social agency, which had done a careful investigation of the suitability of the adoptive parents. An adopted child had the same legal status vis-à-vis the adoptive parents, for example in terms of inheritance, as a biological child, and all formal connections with the biological parents were broken. Typically, the new-born child was initially placed at a special nursery shortly after delivery, and was placed in the adoptive family's home during the child's first few months. ${ }^{4}$ The information and criteria used by the local agencies to match adoptive parents and children most likely generated some positive correlation between the adoptive and biological parents in characteristics like physical appearance and socioeconomic background. ${ }^{5}$ Thus, unlike Sacerdote (2007), we cannot claim statistical independence between the adoptive and biological parents’ socioeconomic status and will need to account explicitly for both.

To identify the six family types we analyze, we need to know the parents of the persons in the two samples. For this purpose, we use two sources provided by Statistics Sweden. The first is the so-called Multi-Generation Register developed by Statistics Sweden for research purposes. This register contains information about biological and adoptive parents of the Swedish population. Thanks to this register, unlike most analyses of adopted children, ours includes information on the adoptees’ biological parents, which the register drew from the legal adoption process. The second source is the censuses conducted by Statistics Sweden in October/November of 1965, 1970, and 1975. From these censuses, we can identify the child's rearing parents as of those dates. Whenever the "census mother" or "census father" is neither a biological nor adoptive parent, we label that parent as a stepparent.

Based on this information, we create samples of six family types (chosen to provide large enough sample sizes to enable meaningful estimates). The six types are:

\footnotetext{
${ }^{4}$ As discussed below, our sample selection criteria include a requirement that the adoptee was present in the adoptive home as of the census in October/November 1965. This further helps assure that most of the sample adoptees were reared by their adoptive parents from an early age.

${ }^{5}$ Björklund, Lindahl, and Plug (2006) report a 0.14 correlation in years of education between the adoptive and biological mothers, and also between the adoptive and biological fathers.
} 
1. Child reared in 1965, 1970, and 1975 by biological mother and father.

2. Biological mother present in the child's household in all three censuses, biological father absent at least once, and no stepfather ever present.

3. Biological mother present in all three censuses, biological father absent at least once, and stepfather present at least once.

4. Biological father present in all three censuses, biological mother absent at least once, and no stepmother ever present.

5. Biological father present in all three censuses, biological mother absent at least once, and stepmother present at least once.

6. Child reared in 1965, 1970, and 1975 by adoptive mother and father.

In this study, we measure rearing and biological parents' socioeconomic status with their years of education. We are reluctant to measure mothers' status by their income or earnings because of women's variable attachment to the paid labor force. This is an especially important concern for our analysis because, during our sample period for adoptions, the local agencies judged prospective adoptive parents to be more suitable if the mother could stay home to care for the child. Our parental education information comes from the 1970 census and Statistics Sweden's 1990 education register. The latter was originally based on the 1970 census data, but was updated by degree information from schools. When the education information differs between the 1990 register and the 1970 census, we use the higher of the two. Like Björklund, Lindahl, and Plug (2006), we assign years of education according to seven categories: 7 for (old) primary school, 9 for (new) compulsory schooling, 11 for short high school, 12 for long high school, 14 for short university, 15.5 for long university, and 19 for Ph.D.

The parental education variables might best be viewed as proxies for some broader concept of the parents' socioeconomic status. The use of proxies raises the issue of errors-in- 
variables bias, but the symmetry of the proxies between the biological and rearing parents makes it likely that any bias is similar for both types of parents, in which case relative comparisons between the two types will not be seriously distorted.

For the offspring generation, we assign years of education in the same way as for the parents except that the children’s education measures are based on Statistics Sweden’s 1999 education register. We also analyze the offspring's 1999 earnings and income, as recorded by Statistics Sweden from tax records. The earnings variable consists of income from work, including self-employment and sickness benefits. The income variable consists of earnings plus some taxable transfers like unemployment benefits and pensions as well as capital income and realized capital gains. We exclude earnings or income observations below SEK 10,000 (about USD 1,200). In 1999, the offspring are 34-37 years old, an age range in which log current income variables as proxies for log long-run income are subject to approximately classical measurement error. ${ }^{6}$

Table 1 displays the sample means and standard deviations of these variables for sons, daughters, and parents in the "balanced" samples for which all the variables are available. The table reveals patterns familiar from previous studies. The best average outcomes for children appear for those raised by both biological parents. Among the various types of parents, the biological parents of adopted children show relatively low average education, and adoptive parents have high average education.

To give a sense of how we arrived at the sample sizes shown in table 1, we will describe how we ended up with a type 6 sample of 1,043 adoptees (556 men and 487 women). To begin with, the number of adoptees born in Sweden between January 1962 and September 1965 that were still alive and living in Sweden in 1999 is 4,085. Some of these, especially among those born in 1965, were not living with their adoptive parents as of October/November 1965. Our

\footnotetext{
${ }^{6}$ Haider and Solon (2006) and Böhlmark and Lindquist (2006).
} 
requirement that the children resided with the adoptive parents as of the 1965 census reduces the sample to 3,122. To assure that the adoptive parents are properly regarded as the rearing parents, we also require that the children continued to reside with both adoptive parents as of the 1970 and 1975 censuses. This reduces the sample to 2,790. The most serious loss of sample observations (to be discussed in more detail shortly) occurs because, for almost half of the children put up for adoption, the biological father was not identified. Our requirement that the biological father be identified reduces the sample to 1,468. In a few instances, the biological mother was not identified in our data, and that further reduces the sample to 1,405. Our requirement that we observe all four parents' education reduces the sample to 1,210. The requirement that we observe the child's education reduces the sample to 1,181 . Finally, the requirement that the child's earnings and income in 1999 exceed SEK 10,000 reduces the sample to 1,043 . As noted below in footnote 11 , skipping the last requirement and using the sample of 1,181 in the analysis of adopted children's education hardly affects the results at all.

Clearly, the most worrisome sample loss (which pertains only to type 6 families) arises from the missing information on adoptees’ biological fathers. The concern here is whether nonrandomness in which fathers are missing will bias the coefficient estimation in our regressions of adopted children's outcomes on the education variables for their four parents. As noted by Björklund, Lindahl, and Plug (2006), even when the biological father's information is missing, it is still possible to estimate regressions of the child's education on the two mothers' education variables. Suppose the fathers’ coefficients were dramatically different between the subsamples with and without information on the biological fathers. Then, in regressions including only the maternal variables, the estimated coefficients of the maternal variables probably would be sensitive to whether the cases with missing information on biological fathers were included (since, according to the familiar omitted-variables formula, the estimated coefficients of the maternal variables would depend on the coefficients of the omitted paternal variables). In fact, 
Björklund, Lindahl, and Plug find very similar results regardless of whether those cases are included. Accordingly, although we would prefer to have information on all the biological fathers, we doubt that losing the cases with missing information will seriously distort our results.

\section{Statistical Models and Estimation Methods}

If everyone were reared by one mother and one father, a simple and easily interpreted model of the intergenerational transmission of socioeconomic status would be

$$
y_{i}=\beta_{m} B_{m i}+\beta_{f} B_{f i}+\alpha_{m} R_{m i}+\alpha_{f} R_{f i}+\gamma^{\prime} D_{i}+\varepsilon_{i}
$$

where $y_{i}$ is a measure of the socioeconomic status of individual $i, B_{m i}$ and $B_{f i}$ are measures of the socioeconomic status of individual $i$ 's biological mother and father, $R_{m i}$ and $R_{f i}$ are measures of the socioeconomic status of the rearing mother and father (who may or may not be the biological parents), $D_{i}$ is a vector of dummy variables for family types (e.g., to allow for a shift in the conditional mean of $y_{i}$ if individual $i$ is raised by adoptive rather than biological parents ${ }^{7}$ ), and $\varepsilon_{i}$ is an error term orthogonal to the explanatory variables.

For an adopted child (in our family type 6), the four parental variables pertain to four distinct parents. With the biological parents' socioeconomic status separately controlled for, the $\alpha$ coefficients for the adoptive parents' socioeconomic status are meant to reflect post-birth environmental influences associated with growing up with the adoptive parents. With the adoptive parents' socioeconomic status separately controlled for, the $\beta$ coefficients for the biological parents’ socioeconomic status are meant to reflect pre-birth influences, including genetic factors as well as the pre-natal environment.

For a child raised by both biological parents (in our family type 1), there are only two distinct parental variables, one for the mother and one for the father. If equation (1) is taken 
literally, the coefficient of the mother’s socioeconomic status variable becomes the sum $\beta_{m}+\alpha_{m}$, which combines the mother's pre-birth and post-birth influences, and the coefficient of the father's socioeconomic status $\beta_{f}+\alpha_{f}$ combines his pre-birth and post-birth influences.

This linearly additive model's characterization of intergenerational status transmission is almost absurdly simplistic. For example, it completely ignores all the interactions of nature and nurture discussed by Ridley (2003). Nevertheless, the results from Björklund, Lindahl, and Plug (2006) that we discussed in section 1 suggest the possibility that this very simple model may do a decent job of characterizing intergenerational transmission of certain socioeconomic variables, at least for Swedes born in 1962-1965. In the next section, we explore that possibility with evidence from all six family types for which we have useful sample sizes.

Our empirical analysis proceeds in two stages. In the first stage, for sons and daughters separately, we perform ordinary least squares (OLS) estimation of regressions of child's adult socioeconomic status on all parents' socioeconomic status for each of the six family types separately. For example, for family type 3, we estimate a regression of the child's outcome on the socioeconomic status variables for the biological mother, the at-least-sometime-absent biological father, and the stepfather. In the first stage, we estimate the regressions separately for each family type, without imposing the restrictions from equation (1), in order to provide a transparent view of the empirical intergenerational associations for each family type.

In the second stage, we put the model in equation (1) to work. In particular, taking the first-stage coefficient estimates as the data, we use minimum distance methods to fit the parameters from a generalized version of model (1) to these data. The generalization of the model is needed to deal with the complications that some children are raised by only one parent and some experience changes of rearing parents during the course of their childhood. Thus, in

\footnotetext{
${ }^{7}$ There is a large literature on differences in child outcomes across family structures. See, for example, McLanahan and Sandefur (1994) and Biblarz and Raftery (1999).
} 
family type 3 for example, we will model the coefficients for the biological father and stepfather respectively as $\beta_{f}+\rho_{3 B} \alpha_{f}$ and $\rho_{3 R} \alpha_{f}$. The point of the additional $\rho$ parameters is to recognize that these not-always-present fathers may have different post-birth influences than the rearing fathers in family types 1 (biological) and 6 (adoptive), who are present in all the observation periods.

The purpose of the model-fitting exercise is not to ascertain whether the generalized version of equation (1) is the true data-generating process for children's socioeconomic outcomes. We know it is not. The point is to assess whether the model delivers a serviceable approximation to the intergenerational associations actually observed. If it does, then the estimated parameters of the admittedly simplistic model may serve as useful statistics for summarizing the pre- and post-birth components of intergenerational status transmission. ${ }^{8}$

\section{Empirical Results}

Starting with first-stage regressions, table 2 displays the coefficient estimates from applying OLS to regressions of son's or daughter's years of education on the years of education of all the child's parents. To account for cohort and life-cycle effects, the regressions also include controls for the ages of both the children and the parents. ${ }^{9}$ In the regression for sons raised by both biological parents (family type 1), the coefficient estimates are 0.172 (with estimated standard error 0.005) for mother's education and $0.197(0.005)$ for father's education. For adopted sons (family type 6), the coefficient estimates are respectively 0.111 (0.036) and

\footnotetext{
${ }^{8}$ Similarly, in our analysis of siblings’ earnings correlations in Björklund, Jäntti, and Solon (2005), we estimated several variants of a simple variance components model. One of those variants allowed for correlation between nurture and nature effects because we figured that individuals with genes conducive to high earnings also might tend to enjoy advantageous environments. Somewhat to our surprise, we found that allowing for such correlation did not improve the model's fit much at all, and the estimated correlations were insignificantly negative. Our conclusion was not that nature-nurture correlation is utterly nonexistent, but rather that modeling it turned out in this instance to be inessential for achieving a useful empirical decomposition of nature and nurture effects.

${ }^{9}$ Björklund, Lindahl, and Plug (2006) also control for region dummies. For the family types common to their study and ours (types 1 and 6), the estimated regression coefficients for the parental education variables are qualitatively similar across the two studies.
} 
$0.118(0.034)$ for the biological mother and father and $0.053(0.032)$ and $0.077(0.030)$ for the adoptive mother and father. The table also reports results for the sons' other four family types and the corresponding results for daughters. Finally, because the estimated coefficients of the parental education variables are fairly similar between the sons and daughters samples, we also report estimates for combined samples that pool the genders while including a dummy variable for gender.

Inspection of the table reveals several striking patterns. First, relatively large coefficient estimates appear for biological parents who rear their children. This is to be expected as these coefficients reflect the combination of pre-birth and post-birth influences. Second, the coefficient estimates for biological parents are substantial even for biological parents who are partly or completely absent from the post-birth environment. This pattern is suggestive of substantial pre-birth (including genetic) influences. ${ }^{10}$ Third, the table also contains indications of important post-birth environmental influences. The coefficient estimates for non-biological rearing parents are almost always positive and often statistically significant. Also, the coefficient estimates tend to be larger for biological parents who raise their children than for non-rearing biological parents. Finally, many comparisons of coefficient estimates offer some hope that a model like that in equation (1) might provide an adequate approximation to the empirical patterns. For example, the coefficient estimates for biological parents who raise their children are fairly similar across different family types, and they also are fairly close to the sums of the coefficient estimates for the biological and rearing parents in the adoptive families.

Table 3 presents the results from parallel analyses with the sons’ and daughters' log earnings in 1999 as the dependent variable. ${ }^{11}$ The broad-brush patterns are similar to those for

\footnotetext{
${ }^{10}$ Björklund, Lindahl, and Plug (2006) argue that the tendency for the coefficient estimates to be as large for nonrearing biological fathers as for non-rearing biological mothers can be construed as evidence that the pre-birth influences come mostly from genetic factors rather than the pre-birth environment in the mother's womb.

${ }^{11}$ As the comparison of sample sizes makes clear, the analyses in tables 2 and 3 are based on the exact same samples. We can slightly increase the sample sizes for our education regressions in table 2 by adding observations 
education in table 2, but the estimated coefficients are less precisely estimated (relative to the magnitudes of the coefficient estimates) and are considerably less stable. Thus, for example, negative coefficient estimates appear more frequently in table 3, especially for daughters, but they are not significantly different from zero, and often their 95 percent confidence intervals contain substantial positive values. Perhaps a single year's earnings information is not a sufficiently reliable indicator of socioeconomic status. This may be especially so for women in the 33-37 age range, given their variable attachment to the paid labor force. ${ }^{12}$ In analyses not reported in the tables, we also have estimated regressions for log individual income and a quite messy and imperfect version of log family income. In their broad-brush patterns and their imprecision, the results are similar to those in table 3.

We have noted several patterns in the regression results, but how can we achieve a succinct quantitative summary of those patterns? One approach is to proceed to our second stage - the fitting of the generalized version of equation (1) to the estimated regression coefficients. The generalized model is fully detailed in table 4, which shows the model's parameterization of each coefficient estimated in the regression tables. As in equation (1), the $\beta$ parameters represent pre-birth influences, and the $\alpha$ parameters represent post-birth influences of alwayspresent rearing parents. The generalization beyond equation (1) is the addition of the six $\rho$ parameters, which allow the post-birth influences of stepparents and sometime-absent biological parents to differ from the $\alpha$ post-birth influences of always-present rearing parents and the assumed zero post-birth influences of never-present biological parents. As the table shows, the model characterizes the 16 regression coefficients with 10 parameters, so the model is overidentified.

excluded from table 3 because the earnings variable is less than SEK 10,000. Doing so produces almost no change from the results reported in table 2.

${ }^{12}$ Böhlmark and Lindquist (2006) report that, for Swedes born in 1948-1950, the reliability ratios for log annual earnings observed in the mid thirties as a proxy for log lifetime earnings are less than 0.5 for men and less than 0.3 for women. 
We use a minimum distance approach to fit the model's parameters to the estimated regression coefficients. In particular, the results in tables 5 and 6 are based on a weighted nonlinear least squares procedure that minimizes a weighted sum of squared discrepancies between the 16 estimated regression coefficients and the fitted values based on the 10 parameters. The 16 observations in this second-stage regression are weighted inversely to their standard error estimates from the first stage. For example, because our type 1 sample of sons raised by both biological parents contains almost 30,000 individuals, the estimated coefficients from their education regression have estimated standard errors of only about 0.005 . The type 5 sample of sons raised by their biological fathers and stepmothers contains fewer than 300 individuals, so the estimated standard errors of the estimated regression coefficients are an order of magnitude larger than those from the type 1 sample. The weighting in our second-stage estimation appropriately recognizes that the type 1 coefficient estimates are much more precise and informative, and therefore our fitted parameter values are much more influenced by the type 1 estimates. $^{13}$

Table 5 reports the estimated parameter values for sons and daughters, and table 6 shows how well the first-stage estimates of regression coefficients are matched by the fitted model. The first and third columns of numbers in table 6 list exactly the same estimated regression coefficients (and associated standard error estimates) as were displayed in table 2. The second and fourth columns list the corresponding fitted values from the model. The asterisked values

\footnotetext{
${ }^{13}$ We also have used an "optimal minimum distance” procedure that takes account of the non-zero covariances among estimated coefficients within the same regressions. The results are similar to the "diagonally weighted" results we report in tables 5 and 6 . By emphasizing the diagonally weighted results, we are focusing on the model's goodness of fit for the estimated regression coefficients, instead of for linear combinations of those estimated coefficients. Our standard error estimates in table 5 take into account the non-zero covariances among estimated coefficients.
} 
are guaranteed to fit exactly because of the free $\rho$ parameters. ${ }^{14}$ And the fitted values shown in the first two rows for the type 1 families fit extremely well by design: because our second-stage estimation places very heavy weights on those observations, it sees to it that those fits are close. What is more interesting for assessing the model's performance is the fit of the unasterisked values from the fourth row down. One could read those results as half-full or half-empty, but our view is that, given the extreme simplicity of the linearly additive model, it fits the data surprisingly well. In most instances, the match between the estimated coefficient and the fitted value is fairly close, especially as compared to the estimated coefficient's standard error estimate.

It has become customary in studies using minimum distance estimation to report $\chi^{2}$ goodness-of-fit statistics, and we present these in the bottom row of table 6. For both sons and daughters, the p-values are about 0.3 , so a naïve interpretation might be to “accept” a null hypothesis that our highly simplistic model is the true data-generating process. We fully understand, however, that that null hypothesis is utterly implausible. Instead, we read the goodness-of-fit statistics as according with our impression that the linearly additive model summarizes the data patterns surprisingly well.

Taking the model as providing an adequate approximation to the empirical intergenerational associations, what can we learn from the model's estimated parameters in table 5? Most of the $\rho$ parameters, which rescale the stepparents' and sometime-absent biological parents' post-birth influences relative to those of always-present parents, are estimated with poor precision, but most are estimated to lie between 0 and 1 as one might expect. Of more central

\footnotetext{
${ }^{14}$ As a result, the 6 out of 16 regression coefficients that involve $\rho$ parameters have no influence on the estimation of the $\beta$ and $\alpha$ parameters. In effect, those data points are "dummied out." If we used only the 10 other estimated regression coefficients as the data for estimating the four $\beta$ and $\alpha$ parameters, the estimates of those parameters still would be exactly as reported in table 5 . The reason we choose to use all 16 estimated regression coefficients to estimate all 10 parameters is for the benefit of readers who would like to view the estimates of the $\rho$ parameters.
} 
interest to our study are the estimates of the $\beta$ and $\alpha$ parameters, which respectively represent the pre-birth (including genetic) and post-birth components of intergenerational status transmission. All eight of those parameter estimates in table 5 are positive, most are quite substantial, and all but one are significantly greater than zero at conventional levels of statistical significance.

These results formalize the eyeball impressions we previously drew from the tables of estimated regression coefficients. The adult socioeconomic status of Swedes born between 1962 and 1965 appears to be positively associated with the socioeconomic status of both their biological parents and their rearing parents, when those parents are not the same as each other as well as when they are. Accordingly, our paper is entitled “Nature and Nurture,” not "Nature vs. Nurture.” We see no logical or empirical need to choose between the two. Our evidence suggests substantial importance for both.

We should add that these results pertain to a relatively rich society with a well-developed welfare state. It is quite conceivable that, in a less developed country, the variation in post-birth environment might encompass a range in which environmental impacts are larger. If researchers can obtain data as rich as ours for other societies, that information would be highly illuminating.

\section{Summary}

Why is socioeconomic status correlated between parents and children? Our paper seeks clues from an extraordinary data set with intergenerational information on a large sample of Swedish families. Our sample contains individuals raised by both biological parents, by adoptive parents, or by one biological parent with or without a stepparent. Relative to previous studies, the most unusual and valuable feature of our data set is that it contains information on the socioeconomic status of biological parents even when they are not the rearing parents. 
We initially characterize the intergenerational transmission of socioeconomic status in terms of regressions of offspring's status on the status of all parents, biological and rearing. Then we summarize the results within the framework of a simple additive model of pre-birth (including genetic) and post-birth environmental factors. Our results suggest that, for Swedes born between 1962 and 1965, both types of factors have played important roles. 
Table 1. Sample means (and standard deviations) by family type

\begin{tabular}{|c|c|c|c|c|c|c|}
\hline & Type 1 & Type 2 & Type 3 & Type 4 & Type 5 & Type 6 \\
\hline \multicolumn{7}{|l|}{ Sons samples } \\
\hline Son's years of education & $\begin{array}{l}12.13 \\
(2.30)\end{array}$ & $\begin{array}{l}11.66 \\
(2.17)\end{array}$ & $\begin{array}{l}11.50 \\
(2.17)\end{array}$ & $\begin{array}{l}11.48 \\
(2.18)\end{array}$ & $\begin{array}{l}11.58 \\
(2.34)\end{array}$ & $\begin{array}{l}11.68 \\
(2.08)\end{array}$ \\
\hline Son’s log earnings & $\begin{array}{l}12.32 \\
(0.61)\end{array}$ & $\begin{array}{l}12.20 \\
(0.72)\end{array}$ & $\begin{array}{l}12.18 \\
(0.75)\end{array}$ & $\begin{array}{l}12.21 \\
(0.75)\end{array}$ & $\begin{array}{l}12.17 \\
(1.02)\end{array}$ & $\begin{array}{l}12.19 \\
(0.88)\end{array}$ \\
\hline Son's log income & $\begin{array}{l}12.40 \\
(0.51)\end{array}$ & $\begin{array}{l}12.32 \\
(0.60)\end{array}$ & $\begin{array}{l}12.29 \\
(0.62)\end{array}$ & $\begin{array}{l}12.31 \\
(0.67)\end{array}$ & $\begin{array}{l}12.29 \\
(0.94)\end{array}$ & $\begin{array}{l}12.33 \\
(0.73)\end{array}$ \\
\hline $\begin{array}{l}\text { Biological father's years of } \\
\text { education }\end{array}$ & $\begin{array}{c}9.98 \\
(3.20)\end{array}$ & $\begin{array}{l}10.01 \\
(3.12)\end{array}$ & $\begin{array}{c}9.56 \\
(2.84)\end{array}$ & $\begin{array}{c}9.51 \\
(3.00)\end{array}$ & $\begin{array}{l}10.08 \\
(3.29)\end{array}$ & $\begin{array}{c}9.33 \\
(2.57)\end{array}$ \\
\hline $\begin{array}{l}\text { Biological mother's years of } \\
\text { education }\end{array}$ & $\begin{array}{c}9.89 \\
(2.87)\end{array}$ & $\begin{array}{l}10.10 \\
(2.86)\end{array}$ & $\begin{array}{l}10.00 \\
(2.65)\end{array}$ & $\begin{array}{c}9.53 \\
(2.66)\end{array}$ & $\begin{array}{c}9.93 \\
(3.03)\end{array}$ & $\begin{array}{c}9.38 \\
(2.53)\end{array}$ \\
\hline $\begin{array}{l}\text { Step/adoptive father's years of } \\
\text { education }\end{array}$ & & & $\begin{array}{c}9.85 \\
(2.88)\end{array}$ & & & $\begin{array}{l}10.26 \\
(3.25)\end{array}$ \\
\hline $\begin{array}{l}\text { Step/adoptive mother's years of } \\
\text { education }\end{array}$ & & & & & $\begin{array}{l}10.62 \\
(2.88)\end{array}$ & $\begin{array}{c}9.89 \\
(3.03)\end{array}$ \\
\hline Number of observations & 28,316 & 2,510 & 1,413 & 772 & 260 & 556 \\
\hline \multicolumn{7}{|l|}{ Daughters samples } \\
\hline Daughter's years of education & $\begin{array}{l}12.40 \\
(2.14)\end{array}$ & $\begin{array}{l}11.85 \\
(2.15)\end{array}$ & $\begin{array}{l}11.59 \\
(2.06)\end{array}$ & $\begin{array}{l}11.65 \\
(1.96)\end{array}$ & $\begin{array}{l}11.94 \\
(2.23)\end{array}$ & $\begin{array}{l}11.93 \\
(2.07)\end{array}$ \\
\hline Daughter's log earnings & $\begin{array}{l}11.89 \\
(0.63)\end{array}$ & $\begin{array}{l}11.79 \\
(0.74)\end{array}$ & $\begin{array}{l}11.79 \\
(0.75)\end{array}$ & $\begin{array}{l}11.75 \\
(0.84)\end{array}$ & $\begin{array}{l}11.83 \\
(1.14)\end{array}$ & $\begin{array}{l}11.79 \\
(0.88)\end{array}$ \\
\hline Daughter's log income & $\begin{array}{l}12.04 \\
(0.49)\end{array}$ & $\begin{array}{l}11.98 \\
(0.57)\end{array}$ & $\begin{array}{l}11.99 \\
(0.58)\end{array}$ & $\begin{array}{l}11.97 \\
(0.68)\end{array}$ & $\begin{array}{l}12.00 \\
(1.06)\end{array}$ & $\begin{array}{l}11.99 \\
(0.72)\end{array}$ \\
\hline $\begin{array}{l}\text { Biological father’s years of } \\
\text { education }\end{array}$ & $\begin{array}{c}9.97 \\
(3.18)\end{array}$ & $\begin{array}{c}9.91 \\
(3.11)\end{array}$ & $\begin{array}{c}9.65 \\
(2.86)\end{array}$ & $\begin{array}{c}9.28 \\
(2.85)\end{array}$ & $\begin{array}{l}10.25 \\
(3.61)\end{array}$ & $\begin{array}{c}9.15 \\
(2.60)\end{array}$ \\
\hline $\begin{array}{l}\text { Biological mother's years of } \\
\text { education }\end{array}$ & $\begin{array}{c}9.86 \\
(2.87)\end{array}$ & $\begin{array}{l}10.07 \\
(2.79)\end{array}$ & $\begin{array}{c}9.91 \\
(2.66)\end{array}$ & $\begin{array}{c}9.41 \\
(2.66)\end{array}$ & $\begin{array}{c}9.98 \\
(3.12)\end{array}$ & $\begin{array}{c}9.51 \\
(2.49)\end{array}$ \\
\hline $\begin{array}{l}\text { Step/adoptive father's years of } \\
\text { education }\end{array}$ & & & $\begin{array}{c}9.86 \\
(2.84)\end{array}$ & & & $\begin{array}{l}10.51 \\
(3.33)\end{array}$ \\
\hline $\begin{array}{l}\text { Step/adoptive mother's years of } \\
\text { education }\end{array}$ & & & & & $\begin{array}{l}10.51 \\
(3.20)\end{array}$ & $\begin{array}{c}9.74 \\
(3.13)\end{array}$ \\
\hline Number of observations & 26,596 & 2,523 & 1,516 & 699 & 181 & 487 \\
\hline
\end{tabular}

Notes: As detailed in the text, the six family types are: (1) reared by biological mother and father, (2) reared by biological mother with no stepfather, (3) reared by biological mother with stepfather, (4) reared by biological father with no stepmother, (5) reared by biological father with stepmother, and (6) reared by adoptive mother and father. 
Table 2. Estimated coefficients in regressions of child's years of education on parents' years of education

\begin{tabular}{|c|c|c|c|c|c|c|}
\hline & Type 1 & Type 2 & Type 3 & Type 4 & Type 5 & Type 6 \\
\hline \multicolumn{7}{|l|}{ Sons samples } \\
\hline $\begin{array}{l}\text { Biological father's years of } \\
\text { education }\end{array}$ & $\begin{array}{c}0.197 \\
(0.005)\end{array}$ & $\begin{array}{c}0.189 \\
(0.014)\end{array}$ & $\begin{array}{c}0.150 \\
(0.020)\end{array}$ & $\begin{array}{c}0.159 \\
(0.028)\end{array}$ & $\begin{array}{c}0.255 \\
(0.044)\end{array}$ & $\begin{array}{l}0.118 \\
(0.034)\end{array}$ \\
\hline $\begin{array}{l}\text { Biological mother's years of } \\
\text { education }\end{array}$ & $\begin{array}{c}0.172 \\
(0.005)\end{array}$ & $\begin{array}{c}0.161 \\
(0.015)\end{array}$ & $\begin{array}{c}0.133 \\
(0.022)\end{array}$ & $\begin{array}{c}0.139 \\
(0.031)\end{array}$ & $\begin{array}{c}0.149 \\
(0.046)\end{array}$ & $\begin{array}{c}0.111 \\
(0.036)\end{array}$ \\
\hline $\begin{array}{l}\text { Step/adoptive father's years of } \\
\text { education }\end{array}$ & & & $\begin{array}{c}0.099 \\
(0.021)\end{array}$ & & & $\begin{array}{c}0.077 \\
(0.030) \\
\end{array}$ \\
\hline $\begin{array}{l}\text { Step/adoptive mother's years of } \\
\text { education }\end{array}$ & & & & & $\begin{array}{c}0.055 \\
(0.049)\end{array}$ & $\begin{array}{r}0.053 \\
(0.032)\end{array}$ \\
\hline Number of observations & 28,316 & 2,510 & 1,413 & 772 & 260 & 556 \\
\hline & & & & & & \\
\hline \multicolumn{7}{|l|}{ Daughters samples } \\
\hline $\begin{array}{l}\text { Biological father's years of } \\
\text { education }\end{array}$ & $\begin{array}{c}0.153 \\
(0.004)\end{array}$ & $\begin{array}{c}0.159 \\
(0.014)\end{array}$ & $\begin{array}{c}0.120 \\
(0.019)\end{array}$ & $\begin{array}{c}0.107 \\
(0.027)\end{array}$ & $\begin{array}{c}0.164 \\
(0.053)\end{array}$ & $\begin{array}{c}0.062 \\
(0.036)\end{array}$ \\
\hline $\begin{array}{l}\text { Biological mother's years of } \\
\text { education }\end{array}$ & $\begin{array}{c}0.166 \\
(0.005)\end{array}$ & $\begin{array}{c}0.173 \\
(0.016) \\
\end{array}$ & $\begin{array}{c}0.139 \\
(0.021)\end{array}$ & $\begin{array}{c}0.153 \\
(0.029) \\
\end{array}$ & $\begin{array}{c}0.087 \\
(0.057)\end{array}$ & $\begin{array}{r}0.084 \\
(0.039) \\
\end{array}$ \\
\hline $\begin{array}{l}\text { Step/adoptive father's years of } \\
\text { education }\end{array}$ & & & $\begin{array}{c}0.078 \\
(0.019)\end{array}$ & & & $\begin{array}{c}0.107 \\
(0.033)\end{array}$ \\
\hline $\begin{array}{l}\text { Step/adoptive mother's years of } \\
\text { education }\end{array}$ & & & & & $\begin{array}{c}0.048 \\
(0.051)\end{array}$ & $\begin{array}{l}-0.006 \\
(0.035)\end{array}$ \\
\hline Number of observations & 26,596 & 2,523 & 1,516 & 699 & 181 & 487 \\
\hline & & & & & & \\
\hline \multicolumn{7}{|l|}{ Combined samples } \\
\hline $\begin{array}{l}\text { Biological father's years of } \\
\text { education }\end{array}$ & $\begin{array}{c}0.176 \\
(0.003)\end{array}$ & $\begin{array}{c}0.174 \\
(0.010)\end{array}$ & $\begin{array}{c}0.136 \\
(0.014)\end{array}$ & $\begin{array}{c}0.135 \\
(0.020)\end{array}$ & $\begin{array}{c}0.214 \\
(0.034)\end{array}$ & $\begin{array}{c}0.089 \\
(0.024)\end{array}$ \\
\hline $\begin{array}{l}\text { Biological mother’s years of } \\
\text { education }\end{array}$ & $\begin{array}{c}0.169 \\
(0.003)\end{array}$ & $\begin{array}{c}0.167 \\
(0.011)\end{array}$ & $\begin{array}{c}0.137 \\
(0.015)\end{array}$ & $\begin{array}{c}0.146 \\
(0.022)\end{array}$ & $\begin{array}{c}0.119 \\
(0.036)\end{array}$ & $\begin{array}{r}0.105 \\
(0.026)\end{array}$ \\
\hline $\begin{array}{l}\text { Step/adoptive father's years of } \\
\text { education }\end{array}$ & & & $\begin{array}{c}0.087 \\
(0.014)\end{array}$ & & & $\begin{array}{c}0.087 \\
(0.022)\end{array}$ \\
\hline $\begin{array}{l}\text { Step/adoptive mother's years of } \\
\text { education }\end{array}$ & & & & & $\begin{array}{c}0.051 \\
(0.036)\end{array}$ & $\begin{array}{r}0.028 \\
(0.024) \\
\end{array}$ \\
\hline Number of observations & 54,912 & 5,033 & 2,929 & 1,471 & 441 & 1,043 \\
\hline
\end{tabular}

Notes: Numbers in parentheses are estimated standard errors. Every regression includes a linear age control for the children (who are in the 34-37 age range in 1999) and quadratic controls for the birth year of each parent. The regressions that combine the sons and daughters samples also control for a gender dummy. As detailed in the text, the six family types are: (1) reared by biological mother and father, (2) reared by biological mother with no stepfather, (3) reared by biological mother with stepfather, (4) reared by biological father with no stepmother, (5) reared by biological father with stepmother, and (6) reared by adoptive mother and father. 
Table 3. Estimated coefficients in regressions of child's 1999 log earnings on parents' years of education

\begin{tabular}{|c|c|c|c|c|c|c|}
\hline & Type 1 & Type 2 & Type 3 & Type 4 & Type 5 & Type 6 \\
\hline \multicolumn{7}{|l|}{ Sons samples } \\
\hline $\begin{array}{l}\text { Biological father's years of } \\
\text { education }\end{array}$ & $\begin{array}{c}0.0181 \\
(0.0013)\end{array}$ & $\begin{array}{c}0.0160 \\
(0.0048)\end{array}$ & $\begin{array}{c}0.0210 \\
(0.0068)\end{array}$ & $\begin{array}{c}0.0095 \\
(0.0086)\end{array}$ & $\begin{array}{c}0.0167 \\
(0.0155)\end{array}$ & $\begin{array}{c}0.0226 \\
(0.0124)\end{array}$ \\
\hline $\begin{array}{l}\text { Biological mother's years of } \\
\text { education }\end{array}$ & $\begin{array}{c}0.0163 \\
(0.0015)\end{array}$ & $\begin{array}{c}0.0112 \\
(0.0052)\end{array}$ & $\begin{array}{c}0.0093 \\
(0.0076)\end{array}$ & $\begin{array}{c}0.0201 \\
(0.0096)\end{array}$ & $\begin{array}{c}0.0121 \\
(0.0162)\end{array}$ & $\begin{array}{c}0.0280 \\
(0.0134)\end{array}$ \\
\hline $\begin{array}{l}\text { Step/adoptive father's years of } \\
\text { education }\end{array}$ & & & $\begin{array}{c}0.0229 \\
(0.0069) \\
\end{array}$ & & & $\begin{array}{c}0.0109 \\
(0.0112) \\
\end{array}$ \\
\hline $\begin{array}{l}\text { Step/adoptive mother's years } \\
\text { of education }\end{array}$ & & & & & $\begin{array}{c}0.0398 \\
(0.0175)\end{array}$ & $\begin{array}{l}-0.0223 \\
(0.0119) \\
\end{array}$ \\
\hline Number of observations & 28,316 & 2,510 & 1,413 & 772 & 260 & 556 \\
\hline & & & & & & \\
\hline \multicolumn{7}{|l|}{ Daughters samples } \\
\hline $\begin{array}{l}\text { Biological father's years of } \\
\text { education }\end{array}$ & $\begin{array}{c}0.0158 \\
(0.0014)\end{array}$ & $\begin{array}{c}0.0215 \\
(0.0049)\end{array}$ & $\begin{array}{c}0.0063 \\
(0.0067)\end{array}$ & $\begin{array}{c}0.0346 \\
(0.0107)\end{array}$ & $\begin{array}{c}0.0281 \\
(0.0206)\end{array}$ & $\begin{array}{l}-0.0092 \\
(0.0129)\end{array}$ \\
\hline $\begin{array}{l}\text { Biological mother's years of } \\
\text { education }\end{array}$ & $\begin{array}{c}0.0154 \\
(0.0016)\end{array}$ & $\begin{array}{c}0.0060 \\
(0.0055)\end{array}$ & $\begin{array}{c}0.0122 \\
(0.0074)\end{array}$ & $\begin{array}{l}-0.0046 \\
(0.0115)\end{array}$ & $\begin{array}{l}-0.0201 \\
(0.0221) \\
\end{array}$ & $\begin{array}{c}0.0212 \\
(0.0140) \\
\end{array}$ \\
\hline $\begin{array}{l}\text { Step/adoptive father's years of } \\
\text { education }\end{array}$ & & & $\begin{array}{c}0.0114 \\
(0.0069)\end{array}$ & & & $\begin{array}{c}0.0192 \\
(0.0119)\end{array}$ \\
\hline $\begin{array}{l}\text { Step/adoptive mother’s years } \\
\text { of education }\end{array}$ & & & & & $\begin{array}{l}-0.0012 \\
(0.0199) \\
\end{array}$ & $\begin{array}{l}-0.0203 \\
(0.0126) \\
\end{array}$ \\
\hline Number of observations & 26,596 & 2,523 & 1,516 & 699 & 181 & 487 \\
\hline
\end{tabular}

Notes: Numbers in parentheses are estimated standard errors. Every regression includes a linear age control for the children (who are in the 34-37 age range in 1999) and quadratic controls for the birth year of each parent. As detailed in the text, the six family types are: (1) reared by biological mother and father, (2) reared by biological mother with no stepfather, (3) reared by biological mother with stepfather, (4) reared by biological father with no stepmother, (5) reared by biological father with stepmother, and (6) reared by adoptive mother and father. 
Table 4. Parametric model for intergenerational regression coefficients

\begin{tabular}{|l|c|c|c|c|c|c|}
\hline & Type 1 & Type 2 & Type 3 & Type 4 & Type 5 & $\begin{array}{c}\text { Type } \\
6\end{array}$ \\
\hline $\begin{array}{l}\text { Biological father's } \\
\text { years of education }\end{array}$ & $\beta_{f}+\alpha_{f}$ & $\beta_{f}+\rho_{2 B} \alpha_{f}$ & $\beta_{f}+\rho_{3 B} \alpha_{f}$ & $\beta_{f}+\alpha_{f}$ & $\beta_{f}+\alpha_{f}$ & $\beta_{f}$ \\
\hline $\begin{array}{l}\text { Biological mother's } \\
\text { years of education }\end{array}$ & $\beta_{m}+\alpha_{m}$ & $\beta_{m}+\alpha_{m}$ & $\beta_{m}+\alpha_{m}$ & $\beta_{m}+\rho_{4 B} \alpha_{m}$ & $\beta_{m}+\rho_{5 B} \alpha_{m}$ & $\beta_{m}$ \\
\hline $\begin{array}{l}\text { Step/adoptive } \\
\text { father's years of } \\
\text { education }\end{array}$ & & $\rho_{3 R} \alpha_{f}$ & & & $\alpha_{f}$ \\
\hline $\begin{array}{l}\text { Step/adoptive } \\
\text { mother's years of } \\
\text { education }\end{array}$ & & & & & $\rho_{5 R} \alpha_{m}$ & $\alpha_{m}$ \\
\hline
\end{tabular}

Notes: As detailed in the text, the six family types are: (1) reared by biological mother and father, (2) reared by biological mother with no stepfather, (3) reared by biological mother with stepfather, (4) reared by biological father with no stepmother, (5) reared by biological father with stepmother, and (6) reared by adoptive mother and father. 
Table 5. Estimated model parameters based on education regressions

\begin{tabular}{|l|c|c|}
\hline & Sons & Daughters \\
\hline$\beta_{f}$ & $0.119(0.023)$ & $0.053(0.024)$ \\
\hline$\beta_{m}$ & $0.114(0.024)$ & $0.132(0.026)$ \\
\hline$\alpha_{f}$ & $0.078(0.023)$ & $0.099(0.024)$ \\
\hline$\alpha_{m}$ & $0.055(0.024)$ & $0.032(0.026)$ \\
\hline$\rho_{2 B}$ & $0.89(0.19)$ & $1.06(0.15)$ \\
\hline$\rho_{3 B}$ & $0.40(0.32)$ & $0.68(0.21)$ \\
\hline$\rho_{3 R}$ & $1.28(0.46)$ & $0.79(0.27)$ \\
\hline$\rho_{4 B}$ & $0.45(0.62)$ & $0.65(0.96)$ \\
\hline$\rho_{5 B}$ & $0.63(0.84)$ & $-1.40(2.62)$ \\
\hline$\rho_{5 R}$ & $0.99(0.99)$ & $1.49(2.00)$ \\
\hline
\end{tabular}

Notes: Numbers in parentheses are estimated standard errors. 
Table 6. Comparison of coefficient estimates from education regressions and values fitted by model

\begin{tabular}{|c|c|c|c|c|}
\hline & \multicolumn{2}{|l|}{ Sons } & \multicolumn{2}{|l|}{ Daughters } \\
\hline Parental education variable & $\begin{array}{c}\text { Coefficient } \\
\text { estimate }\end{array}$ & Fitted value & $\begin{array}{c}\text { Coefficient } \\
\text { estimate }\end{array}$ & Fitted value \\
\hline $\begin{array}{l}\text { Type 1: Biological father’s } \\
\text { years of education }\end{array}$ & $\begin{array}{c}0.197 \\
(0.005)\end{array}$ & 0.197 & $\begin{array}{c}0.153 \\
(0.004)\end{array}$ & 0.152 \\
\hline $\begin{array}{l}\text { Type 1: Biological mother's } \\
\text { years of education }\end{array}$ & $\begin{array}{c}0.172 \\
(0.005)\end{array}$ & 0.169 & $\begin{array}{c}0.166 \\
(0.005)\end{array}$ & 0.164 \\
\hline $\begin{array}{l}\text { Type 2: Biological father’s } \\
\text { years of education }\end{array}$ & $\begin{array}{c}0.189 \\
(0.014)\end{array}$ & $0.189 *$ & $\begin{array}{c}0.159 \\
(0.014)\end{array}$ & $0.159 *$ \\
\hline $\begin{array}{l}\text { Type 2: Biological mother's } \\
\text { years of education }\end{array}$ & $\begin{array}{c}0.161 \\
(0.015)\end{array}$ & 0.169 & $\begin{array}{c}0.173 \\
(0.016)\end{array}$ & 0.164 \\
\hline $\begin{array}{l}\text { Type 3: Biological father’s } \\
\text { years of education }\end{array}$ & $\begin{array}{c}0.150 \\
(0.020)\end{array}$ & $0.150 *$ & $\begin{array}{c}0.120 \\
(0.019)\end{array}$ & $0.120^{*}$ \\
\hline $\begin{array}{l}\text { Type 3: Biological mother's } \\
\text { years of education }\end{array}$ & $\begin{array}{c}0.133 \\
(0.022)\end{array}$ & 0.169 & $\begin{array}{c}0.139 \\
(0.021)\end{array}$ & 0.164 \\
\hline $\begin{array}{l}\text { Type 3: Stepfather's years of } \\
\text { education }\end{array}$ & $\begin{array}{c}0.099 \\
(0.021)\end{array}$ & 0.099* & $\begin{array}{c}0.078 \\
(0.019)\end{array}$ & $0.078^{*}$ \\
\hline $\begin{array}{l}\text { Type 4: Biological father’s } \\
\text { years of education }\end{array}$ & $\begin{array}{c}0.159 \\
(0.028)\end{array}$ & 0.197 & $\begin{array}{c}0.107 \\
(0.027)\end{array}$ & 0.152 \\
\hline $\begin{array}{l}\text { Type 4: Biological mother's } \\
\text { years of education }\end{array}$ & $\begin{array}{c}0.139 \\
(0.031)\end{array}$ & $0.139 *$ & $\begin{array}{c}0.153 \\
(0.029)\end{array}$ & $0.153^{*}$ \\
\hline $\begin{array}{l}\text { Type 5: Biological father’s } \\
\text { years of education }\end{array}$ & $\begin{array}{c}0.255 \\
(0.044) \\
\end{array}$ & 0.197 & $\begin{array}{c}0.164 \\
(0.053) \\
\end{array}$ & 0.152 \\
\hline $\begin{array}{l}\text { Type 5: Biological mother’s } \\
\text { years of education }\end{array}$ & $\begin{array}{c}0.149 \\
(0.046)\end{array}$ & $0.149 *$ & $\begin{array}{c}0.087 \\
(0.057)\end{array}$ & $0.087 *$ \\
\hline $\begin{array}{l}\text { Type 5: Stepmother's years of } \\
\text { education }\end{array}$ & $\begin{array}{c}0.055 \\
(0.049)\end{array}$ & $0.055^{*}$ & $\begin{array}{c}0.048 \\
(0.051)\end{array}$ & $0.048^{*}$ \\
\hline $\begin{array}{l}\text { Type 6: Biological father’s } \\
\text { years of education }\end{array}$ & $\begin{array}{c}0.118 \\
(0.034) \\
\end{array}$ & 0.119 & $\begin{array}{c}0.062 \\
(0.036) \\
\end{array}$ & 0.053 \\
\hline $\begin{array}{l}\text { Type 6: Biological mother’s } \\
\text { years of education }\end{array}$ & $\begin{array}{c}0.111 \\
(0.036)\end{array}$ & 0.114 & $\begin{array}{c}0.084 \\
(0.039)\end{array}$ & 0.132 \\
\hline $\begin{array}{l}\text { Type 6: Adoptive father's years } \\
\text { of education }\end{array}$ & $\begin{array}{c}0.077 \\
(0.030)\end{array}$ & 0.078 & $\begin{array}{c}0.107 \\
(0.033) \\
\end{array}$ & 0.099 \\
\hline $\begin{array}{l}\text { Type 6: Adoptive mother’s } \\
\text { years of education }\end{array}$ & $\begin{array}{c}0.053 \\
(0.032)\end{array}$ & 0.055 & $\begin{array}{l}-0.006 \\
(0.035)\end{array}$ & 0.032 \\
\hline $\begin{array}{l}\chi^{2} \text { goodness-of-fit statistic } \\
\text { (p-value) }\end{array}$ & $\begin{array}{c}6.81 \\
(0.34)\end{array}$ & & $\begin{array}{c}7.72 \\
(0.26)\end{array}$ & \\
\hline
\end{tabular}

Notes: The fitted values with asterisks are guaranteed to fit exactly because of the free $\rho$ parameters. As detailed in the text, the six family types are: (1) reared by biological mother and father, (2) reared by biological mother with no stepfather, (3) reared by biological mother with stepfather, (4) reared by biological father with no stepmother, (5) reared by biological father with stepmother, and (6) reared by adoptive mother and father. 


\section{$\underline{\text { References }}$}

Becker, Gary S., and Nigel Tomes. “An Equilibrium Theory of the Distribution of Income and Intergenerational Mobility.” Journal of Political Economy 87 (1979), pp. 1153-1189.

Becker, Gary S., and Nigel Tomes. "Human Capital and the Rise and Fall of Families.” Journal of Labor Economics 4 (1986), pp. S1-S39.

Biblarz, Timothy J., Adrian E. Raftery, and Alexander Bucur, “Family Structure and Social Mobility.” Social Forces 75 (1997), pp. 1319-1341.

Biblarz, Timothy J., and Adrian E. Raftery. "Family Structure, Educational Attainment, and Socioeconomic Success: Rethinking the 'Pathology of Matriarchy.'” American Journal of Sociology 105 (1999), pp. 321-365.

Björklund, Anders, and Laura Chadwick. "Intergenerational Income Mobility in Permanent and Separated Families.” Economics Letters 80 (2003), pp. 239-246.

Björklund, Anders, Markus Jäntti, and Gary Solon. “Influences of Nature and Nurture on Earnings Variation: A Report on a Study of Various Sibling Types in Sweden,” in Samuel Bowles, Herbert Gintis, and Melissa Osborne Groves, eds., Unequal Chances: Family Background and Economic Success. Princeton: Princeton University Press, 2005, pp. 145-164. Björklund, Anders, Mikael Lindahl, and Erik Plug. “The Origins of Intergenerational Associations: Lessons from Swedish Adoption Data.” Quarterly Journal of Economics 121 (2006), pp. 999-1028.

Böhlmark, Anders, and Matthew J. Lindquist. "Life-Cycle Variations in the Association between Current and Lifetime Income: Replication and Extension for Sweden.” Journal of Labor Economics 24 (2006), pp. 879-896.

Das, Mitali, and Tanja Sjogren. “The Inter-generational Link in Income Mobility: Evidence from Adoptions.” Economics Letters 75 (2002), pp. 55-60. 
Haider, Steven, and Gary Solon. "Life-Cycle Variation in the Association between Current and Lifetime Earnings.” American Economic Review 96 (2006), pp. 1308-1320.

McLanahan, Sara, and Gary Sandefur. Growing Up with a Single Parent: What Hurts, What Helps. Cambridge: Harvard University Press, 1994.

Plug, Erik. “Estimating the Effect of Mother’s Schooling on Children’s Schooling Using a Sample of Adoptees.” American Economic Review 94 (2004), pp. 358-368.

Plug, Erik, and Wim Vijverberg. “Does Family Income Matter for Schooling Outcomes? Using Adoptees as a Natural Experiment.” Economic Journal 115 (2005), pp. 879-906.

Ridley, Matt. Nature via Nurture: Genes, Experience, and What Makes Us Human. New York: Harper Collins, 2003.

Sacerdote, Bruce. “The Nature and Nurture of Economic Outcomes.” Working Paper No. 7949, National Bureau of Economic Research, 2000.

Sacerdote, Bruce. "How Large Are the Effects from Changes in Family Environment? A Study of Korean American Adoptees. Quarterly Journal of Economics 122 (1997), pp. 119-157. Scarr, Sandra, and Richard A. Weinberg. "Educational and Occupational Achievements of Brothers and Sisters in Adoptive and Biologically Related Families.” Behavior Genetics 24 (1994), pp. 301-325.

Solon, Gary. “Intergenerational Mobility in the Labor Market,” in Orley C. Ashenfelter and David Card, eds., Handbook of Labor Economics, vol. 3A. Amsterdam: North-Holland, 1999, pp. 1761-1800.

Solon, Gary. “A Model of Intergenerational Mobility Variation over Time and Place,” in Miles Corak, ed., Generational Income Mobility in North America and Europe. Cambridge: Cambridge University Press, 2004, pp. 38-47.

Solon, Gary. "Intergenerational Income Mobility,” in Steven Durlauf and Lawrence Blume, eds., The New Palgrave Dictionary of Economics, $2^{\text {nd }}$ edition. London: Macmillan, forthcoming. 